\title{
Comparison of air and steam stripping: removal of organic halogen compounds from process wastewaters
}

\author{
A. J. Toth · P. Mizsey
}

Received: 6 April 2013/Revised: 7 December 2013/Accepted: 11 January 2014/Published online: 29 January 2014

(C) Islamic Azad University (IAU) 2014

\begin{abstract}
In the engineering practice, there are two basic alternatives of physicochemical treatment for the removal of volatile compounds from process wastewaters: stripping with air or stripping with steam. In this work, these alternatives are investigated and compared in the case of a real industrial problem that is typical for the fine chemical industry and general conclusion is drawn. The removal of the organically bound halogens, called adsorbable organically bound halogens, is investigated. The two alternatives, air and steam stripping, are first modeled in the professional software environment of ASPEN Plus ${ }^{\circledR}$. The model is validated on the data of an existing air stripper for the removal of organic halogens. Same organic halogens removal is applied for the design of a steam stripper. It is proved that the steam stripping shows better operability and economic performance than the air stripping; moreover, the volatile and/or adsorbable organically bound halogen compounds can be recovered in the distillate and they can be reused improving the sustainability.
\end{abstract}

Keywords Adsorbable organically bound halogens . ASPEN Plus ${ }^{\circledR}$. Cost estimation - Operability features . Pharmaceutical process wastewater $\cdot$ Stripping

\footnotetext{
A. J. Toth $(\bowtie) \cdot$ P. Mizsey

Department of Chemical and Environmental Process Engineering, Faculty of Chemical Technology and Biotechnology, Budapest University of Technology and Economics, Budafoki Street 8, P.O. Box 1521, 1111 Budapest, Hungary

e-mail: ajtoth86@gmail.com

P. Mizsey

Research Institute of Chemical and Process Engineering, University of Pannonia, Egyetem Street 10, P.O. Box 125, 8200 Veszprem, Hungary
}

\section{Introduction}

Stripping belongs to the physicochemical tools applied for process wastewater treatment. Other possible physicochemical alternatives are as follows: rectification, evaporation, membrane separation, wet oxidation, incineration, etc. (Mizsey et al. 2008; Mizsey and Toth 2012). The application of physicochemical tools for the treatment of process wastewaters is improved since the biological tools mainly cannot be applied, for the reason that process wastewaters have pollutant concentration high enough to be detrimental for the biological treatment technology. Moreover, the biological treatment can also be prohibited by local authorities.

Stripping is one of the most frequently used procedures for the removal of volatile organic compounds (VOC) from process wastewater (IPPC Ref. Doc. 2002). Generally, air or steam is used to strip the VOC and the compounds less volatile than water but form minimum boiling azeotropes, frequently heteroazeotropes (Gmehling et al. 1994).

In the stripping process, the wastewater is brought into contact with high amount of hot gas, vapor or steam to bring the volatile organic and/or inorganic contaminants into the gas/vapor phase from the aqueous phase. In the case of air stripping, water is usually also transferred into the gas phase, which lowers the temperature of the hot air, and therefore lowers volatility of the impurities. Impurities are removed from the gas phase used for stripping and the gas/air can be used again. Stripping can be performed as either a batch or a continuous process (Sattler 1977; Driscoll et al. 2008).

Depending on the volatility of the organic contaminant and the nature of the process, several types of strippers can be chosen (Ecker and Winter 2000). In the case of easily removable contaminants, a stripping tank can be used, where air or steam is bubbled into the process wastewater. 


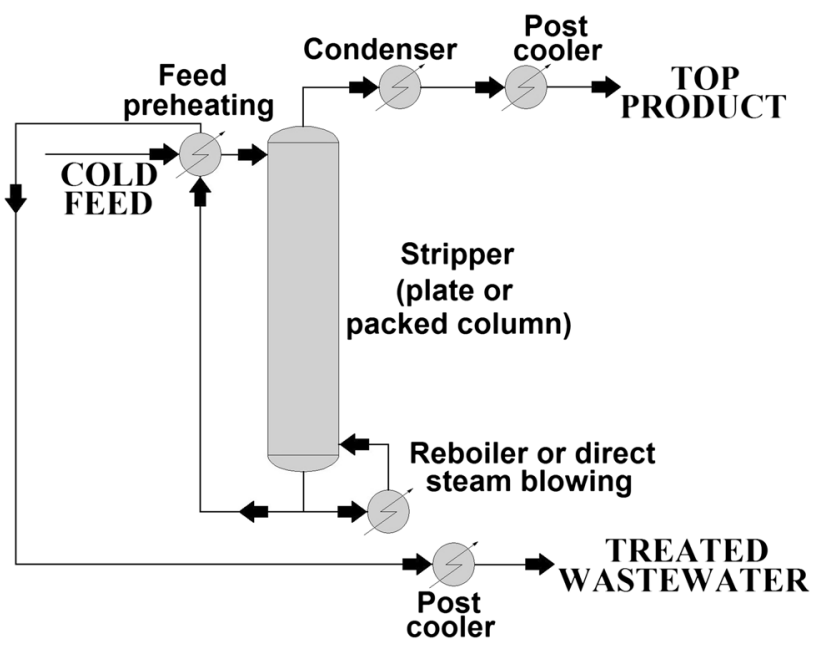

Fig. 1 General schema for wastewater stripping

Packed or tray columns can be properly used to remove the polluting compounds. The process wastewater is fed at the top, and the air or steam is fed at the bottom. The pollutants can be typically found in the top product that can be also called distillate. The treated wastewater is removed at the bottom (BMU 2000; EEA 1997; Sackewitz 1999; NOREC 2000). Figure 1 illustrates a general schema for the last type. It is advisable to use the heat content of the removed warm, treated wastewater to preheat the cold fed wastewater.

Stripping is used to remove volatile organic and/or inorganic contaminants, such as organic solvents, hydrocarbons, aromatic/aryl compounds, chlorinated hydrocarbons, ammonia, and hydrogen sulfide (Basakcilardankabakci et al. 2007; Saracco and Genon 1994; Ecker and Winter 2000).

A general problem with stripping is when the wastewater contains solid contaminants or when solid matter precipitates after stripping. This causes fouling and therefore a breakdown which could contaminate the column and the heat exchangers (BMU 2000; EEA 1997).

Air stripping must not be used alone because the output gases and possible vapors enter the atmosphere and as a consequence the pollution is just transformed from the liquid into the air. In order to avoid it, these gases and vapors have to be treated. Possible methods of purification are as follows: condensation, adsorption, absorption, chemisorption, thermal or catalytic oxidation, and membrane separation (Sackewitz 1999). These methods of treatment are often more complicated and more expensive than the stripping itself.

\section{Comparison of air and steam stripping}

The steam stripping is an alternative of air/inert gas stripping used for less volatile pollutants (IPPC Ref. Doc.
2002). The steam is produced in a steam boiler (Alfke et al. 1999). In chemical plants, however, there is practically always a steam network, so the availability and the application of steam is normally not a problem.

If steam is applied, the volatile stripped compounds do not enter the atmosphere, and they can be condensed and treated, since this is the liquid distillate. In many cases, these liquid products contain the organic pollutants in a concentrated form, and this allows the option to reuse these compounds inside or outside of the technology of their origin. Both operational and economic aspects should be considered when choosing between the two methods (IPPC Ref. Doc. 2002).

The costs of stripping depend on various factors. The exact investment cost can be determined only for a welldefined project, and only that can be the basis for decision between steam stripping and air stripping, if the task allows it (ENTEC 1996).

Many engineers believe that a simple air stripping plant is enough to solve a specific problem. This means, however, that the pollution is transferred from the water phase into the air/inert gas phase. Therefore, the output gases have to be treated using difficult cleaning methods (Quan et al. 2009; Wang et al. 2010) to avoid polluting the atmosphere. Compared with air stripping, the construction and operation of a steam stripping plant are usually simpler and easier (Asia and Akporhonor 2007).

The top product of the steam stripper, sometimes rectifier, is usually the pure VOC that can be reused, and this option is an environmental friendly, green option that favors the steam stripping by far.

This problem, whether air or steam stripping should be favored we investigated on an industrial problem at our department over the last 5 years.

\section{Materials and methods}

Environmental regulations are very severe for the adsorbable organically bound halogens (AOX; DIN 38409-H14 1996). If the AOX content of a process wastewater is higher than the emission limit $(8 \mathrm{ppm})$, the factory is closed. On the contrary, if the concentration of the VOC in process wastewater is higher than the emission limit $\left(1,000 \mathrm{mg} \mathrm{O}_{2} / \mathrm{l}\right)$, the factory will have to pay fine but it can still continue its operation. Moreover, the VOC concentration can be reduced with other tools beside the stripping, e.g., wet oxidation, biological treatment (MohammadHosseini et al. 2011).

But the AOX compounds can be removed only with physicochemical tools and basically with stripping. The AOX compounds can disturb wet oxidation and they inhibit the biological treatment. This is the reason why the AOX 
removal is so important, and our industrial case study focuses on the removal of AOX compounds with stripping. Of course, if stripping is applied, the VOC content is also reduced (Koczka and Mizsey 2010), but in this research, this is out of scope and we just focus on the AOX removal in agreement with the industrial procedure.

Base case for model validation

To study and compare the air and steam stripping, a real pharmaceutical problem is selected. Table 1 shows the polluting compounds of the process wastewater. The AOX compounds are bolded.

As Table 1 shows, the major polluting AOX components of the examined process wastewater are dichloromethane and trichloroethylene. Although other AOX compounds are present in a negligible amount, their presences in the mixture have to be taken into account for the precise vapor-liquid equilibrium calculations.

Table 1 Pollution compounds in a pharmaceutical process wastewater (Major 2008)

\begin{tabular}{l}
\hline Pollution compound $(\mathrm{ppm})$ \\
\hline Acetone 28.9 \\
Ethylbenzene 0.49 \\
Benzene 2.34 \\
Methanol 4.412 \\
-Butanol 66.0 \\
4-Methyl-2-pentanone 0.31 \\
n-Butanol 0.02 \\
2-Pentanone 0.11 \\
Tert-butanol 0.03 \\
1-Propanol 0.02 \\
Carbon tetrachloride $\mathbf{0 . 0 1}$ \\
2-Propanol 21.7 \\
Chloroform $\mathbf{0 . 2 7}$ \\
Tetrachloroethylene $\mathbf{0 . 0 4}$ \\
1,2-Dichloroethane $\mathbf{0 . 3 9}$ \\
Toluene 16.9 \\
Dichloromethane $\mathbf{1 , 0 2 0}$ \\
Trichloroethylene $\mathbf{7 . 1 5}$ \\
Diethyl ether 0.06 \\
$m$-Xylene 1.89 \\
1,4-Dioxane 0.20 \\
$o$-Xylene 0.36 \\
Ethanol 10.9 \\
$p$-Xylene 0.49 \\
Ethyl acetate 1.58 \\
All compound 5,592 \\
All AOX compound 1,028 \\
\hline
\end{tabular}

For a pharmaceutical company, there are several possibilities to lower AOX content of the wastewater (Koczka 2009; Toth et al. 2011; Seiss et al. 2001). It is preferred to first examine whether the organic halogen compounds could be substituted with solvents not containing halogens (Lapkin and Constable 2008; Mizsey 1994). If this is not possible, then the wastewater can be incinerated, distilled, or stripped. It is sensible to recover the solvent content of the process wastewater and use it in other manufacturing processes (Toth et al. 2011; Quan et al. 2010).

In the following, the problem of lowering the AOX content of the wastewater in Table 1 is selected for detailed investigation to obtain generalizable conclusion.

\section{Air stripping plant}

Modeling of process wastewater treatment with different physicochemical tools, among them with stripping, has been studied by several researchers: Ferrer et al. (2008), Marsili-Libelli (2010), Rivas et al. (2008) and Köhler et al. (2007). The simulation of the air stripping plant is carried out according to the engineering structure of a stripping plant. This structure can be seen in Fig. 2. According to the chemical engineering knowledge, in the case of stripping, the feed to be stripped is fed at the top of the stripper. This engineering principle is also true for the steam stripper shown in Fig. 1. The stripper contains some column internals, polyhedral hollow ball in our case (Chempack Co. 2007), to facilitate mass transfer offering area for such purpose. The engineering concept should pay attention to the fact that the stripping with air just passes over the pollution from the water phase into the air/gaseous phase, and therefore the air or stripping gas leaving the stripper should be also treated. Such treatment is usually a burner, that is, an oxidation usually supported with catalyst. After the oxidation, a scrubber-type gas cleaner is used to chemically bind the polluting flue gas compounds.

According to the theory described in the previous considerations, the air stripping plant should consist of three main units:

1. Stripping column, where the desorption of halogens happens,

2. Catalytic oxidation equipment, where the stripped hydrocarbons are oxidized,

3. Gas cleaner with sodium hydroxide, where the output of the oxidation is neutralized by chemisorption.

The model of such a stripping plant is built including the three main units. For the modeling, the professional flow sheet simulation package the ASPEN Plus ${ }^{\circledR}$ is selected and the model of such an air stripper plant including the three main units is built. 
The selected industrial air stripper fully coincides with the theoretically necessary unit operations.

It is not necessary to model the tanks and the filter before the stripping column because they will be the same if air stripping and steam stripping are compared. However, the ventilator is included in the model since the transportation of air is an expensive unit operation (Douglas 1989). The thermodynamic property package is the UNIFAC model (Fredenslund et al. 1975) and is selected at the modeling of the air stripping plant.

The simplified structure of the air stripping plant using the ASPEN symbols is shown in Fig. 2.

The first unit of the air stripping plant is the stripping column. In our industrial case study, the wastewater is fed in the top of the column, with $20 \mathrm{~m}^{3} / \mathrm{h}$ flow rate. At the bottom of the stripping column, a ventilator provides the $2,000 \mathrm{~m}^{3} / \mathrm{h}$ air flow. The packed column is $10 \mathrm{~m}$ high, $1 \mathrm{~m}$ in diameter, and contains polypropylene polyhedral hollow ball packing (Chempack Co. 2007). After the stripping, practically no AOX component remains in the water phase that is to be released into the sewage system, because the stripped compounds leave with the head product in the airflow (Fig. 3).

The polluted airflow leaving the stripper enters the catalytic oxidation equipment (KATOX) through a droplet separator. The air excess necessary for the operation of the KATOX is provided by an additional ventilator which delivers an additional $500 \mathrm{~m}^{3} / \mathrm{h}$ airflow.

The gas flow is heated electrically, the catalyst is made from Pt to Ir, and the pollutants are oxidized at approximately $500{ }^{\circ} \mathrm{C}$. The halogenated hydrocarbons decompose into their chemical components $\left(\mathrm{H}_{2} \mathrm{O}, \mathrm{CO}_{2}, \mathrm{Cl}_{2}, \mathrm{HCl}\right)$ in the equipment. After the catalyst oxidizer, the output gas flows through a heat exchanger, which is for the preheating of the airflow entering the KATOX, using the heat of the airflow leaving it. Thus, energy integration is achieved and the energy needed to heat the flow before the KATOX is significantly lowered, as well as the energy needed for temperature correction in the continuous plant. For the chemical constants (Mizsey 1991), the reaction equations (Oguz et al. 2000) and the models (Simoni et al. 2008) from the literature are used (Fig. 4).

The simulation is interrupted before the gas cleaner, because there are not enough accurate data to build a suitable model of the KATOX. Due to the lack of data regarding the ratio of $\mathrm{Pt}$ to Ir in the catalyst, the reaction constants, and the activation energies in the oxidation reactions, it is not possible to run the simulation of the equipment in the software. Instead, we rely on the information from the pharmaceutical company: The efficiency of the KATOX in their apparatus is

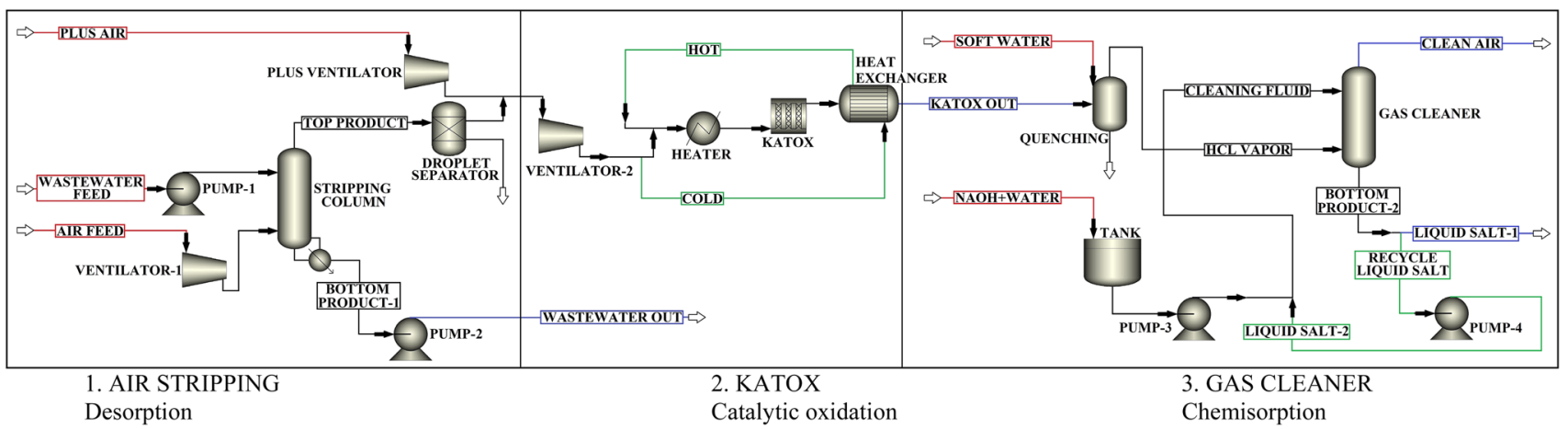

Fig. 2 Air stripping plant (Major 2008)

Fig. 3 Air stripping (Major 2008)

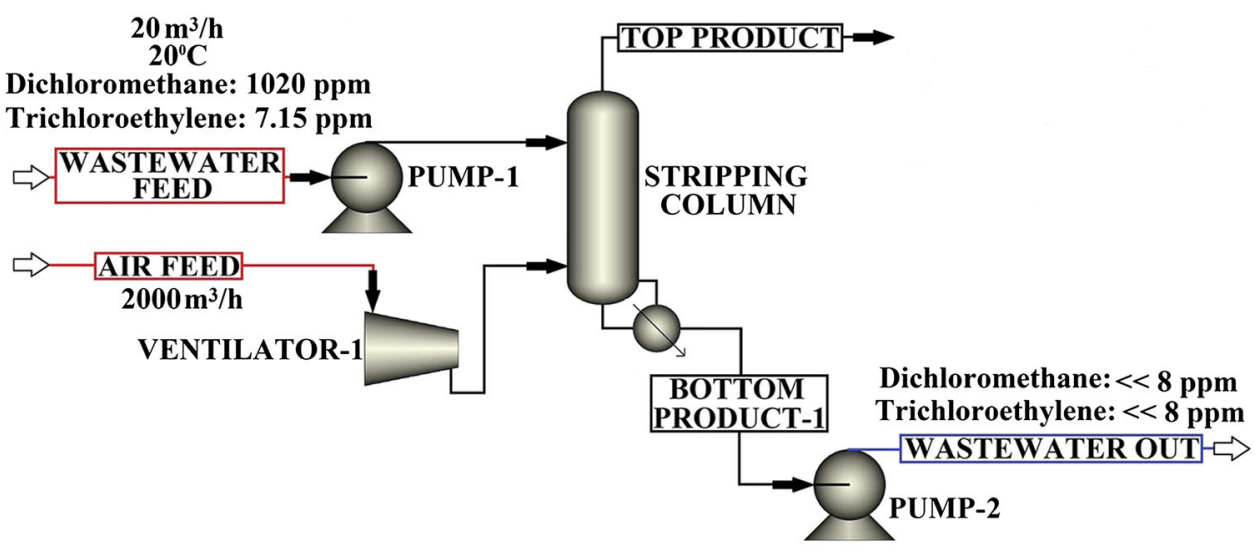


Fig. 4 KATOX (Major 2008)

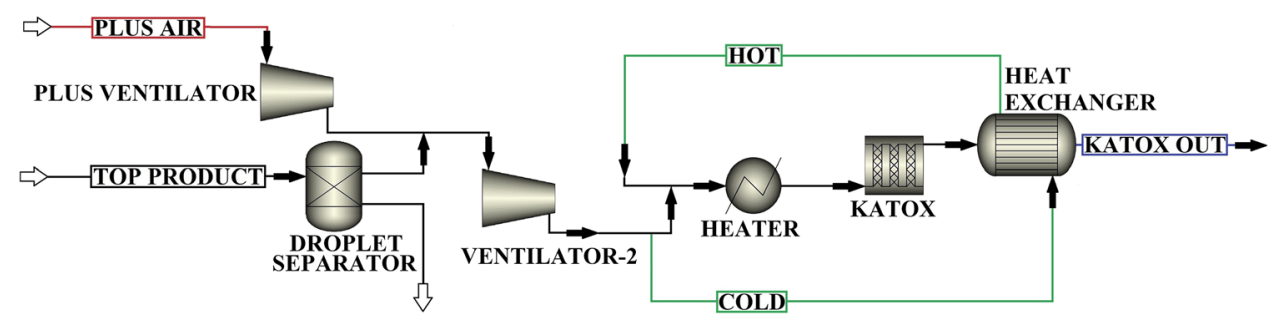

Fig. 5 Gas cleaner (Major 2008)

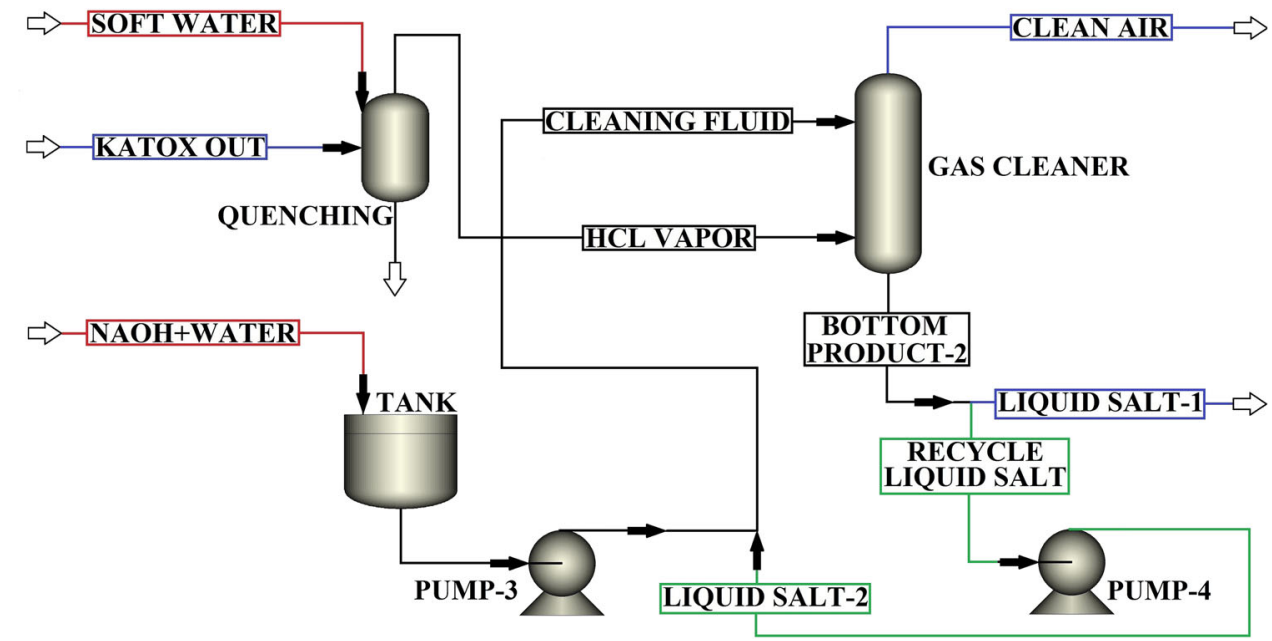

minimum $70 \%$. Thus, we can predict the composition and the amount of the gas flow leaving the KATOX and entering the gas cleaner based on the simulation data of the gas flow entering the KATOX.

During this oxidation, also the Deacon reaction also takes place; however, since this is a slow reaction, only around in the magnitude of $100 \mathrm{ppm}$ chlorine is formed from the hydrochloric acid vapor (Gonzalez-Velasco et al. 1998; Bajnoczy 2013).

The first unit of the gas cleaner model is the quenching tank where the mixture that mainly contains the hydrochloric acid vapor and chlorine gas is cooled down from approximately 250 to around $130^{\circ} \mathrm{C}$.

The gas flow with the oxidized pollutants enters at the bottom of the gas cleaner column, while the $1 \mathrm{~m} / \mathrm{m} \%$ $\mathrm{NaOH}$ cleaning fluid is introduced in countercurrent flow at the top. According to the industrial data, the column is $6 \mathrm{~m}$ high and $63 \mathrm{~cm}$ in diameter, packed with polypropylene polyhedral hollow ball (Chempack Co. 2007).

The hydrochloric acid vapors and chlorine gases are neutralized in the column with chemisorptions, according to the next equation:

$\mathrm{NaOH}+\mathrm{HCl} \rightarrow \mathrm{NaCl}+\mathrm{H}_{2} \mathrm{O}$.

The chlorine present in small concentration is also neutralized according to the following brutto reaction:
$2 \mathrm{NaOH}+\mathrm{Cl}_{2} \rightarrow \mathrm{NaOCl}+\mathrm{NaCl}+\mathrm{H}_{2} \mathrm{O}$.

The head product is clean air, which is released into the atmosphere. The bottom product contains the salt produced during the neutralization. Stoichiometric amount of cleaning fluid is fed into the column, and therefore the bottom product theoretically doesn't contain remaining basic compounds; thus, its $\mathrm{pH}$ is in the range specified by regulations. To lower the amount of chemical lye used for neutralization, $90 \%$ of the bottom product is recycled and $10 \%$ is removed. The deposition of the latter has to be taken care of, because due to its high salt content, releasing it into the sewage system would procure high fines (220/ 2004. (VII. 21.) Government Regulation 2004) (Fig. 5).

Steam stripping plant

In the case of the designed and simulated steam, wastewater stripping crossflow plant, the whole system is simpler built than the previously described air stripping.

Practically, the model consists only of a packed stripping column. To be able to compare the two plants, they are simulated with equal capacity, and therefore the wastewater is introduced likewise at the top with $20 \mathrm{~m}^{3} / \mathrm{h}$ flow rate. The steam based on our calculations enters the bottom of the column with $0.42 \mathrm{~m}^{3} / \mathrm{h}$ flow rate. 


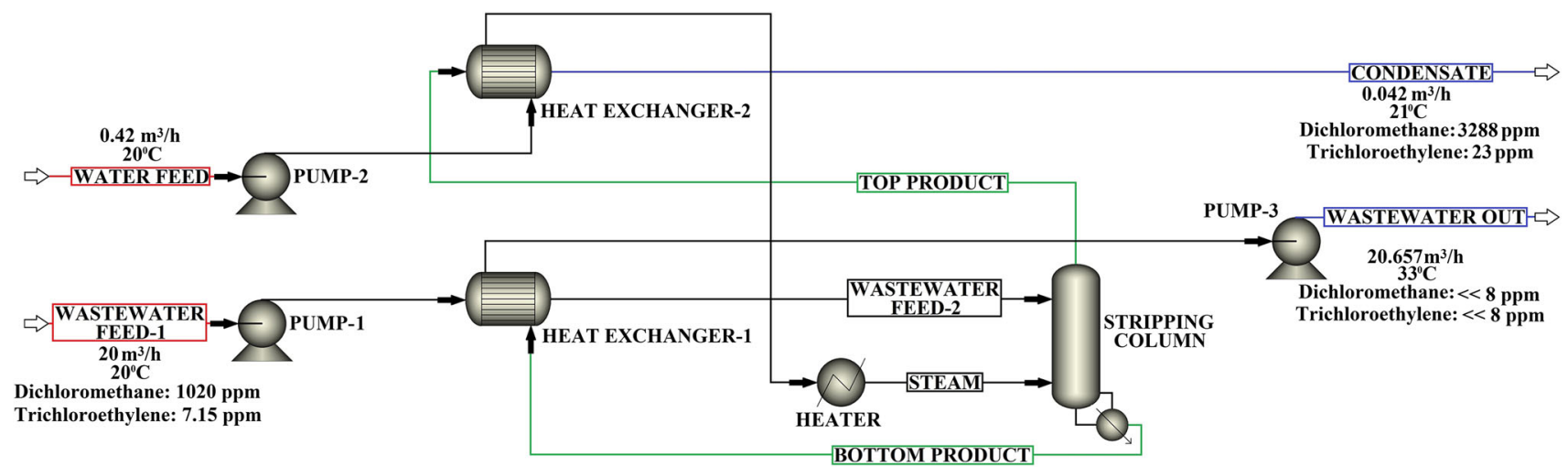

Fig. 6 Steam stripping plant (Major 2008)

Table 2 AOX removal of air and steam stripping (simulated data)

\begin{tabular}{|c|c|c|c|}
\hline \multirow[t]{2}{*}{ AOX compounds } & \multirow[t]{2}{*}{$\begin{array}{l}\text { Wastewater input } \\
(\mathrm{ppm})\end{array}$} & \multicolumn{2}{|c|}{$\begin{array}{l}\text { Wastewater output } \\
\text { (ppm) }\end{array}$} \\
\hline & & $\begin{array}{l}\text { Air } \\
\text { stripping }\end{array}$ & $\begin{array}{l}\text { Steam } \\
\text { stripping }\end{array}$ \\
\hline $\begin{array}{l}\text { Carbon } \\
\text { tetrachloride }\end{array}$ & 0.01 & $3.6 \mathrm{E}-29$ & $9.7 \mathrm{E}-29$ \\
\hline Chloroform & 0.27 & $3.0 \mathrm{E}-28$ & $1.4 \mathrm{E}-18$ \\
\hline 1,2-Dichloroethane & 0.39 & $1.9 \mathrm{E}-28$ & $2.5 \mathrm{E}-12$ \\
\hline Dichloromethane & 1,020 & $6.9 \mathrm{E}-29$ & $5.7 \mathrm{E}-14$ \\
\hline Tetrachloroethylene & 0.04 & $1.4 \mathrm{E}-28$ & $3.7 \mathrm{E}-20$ \\
\hline Trichloroethylene & 7.15 & $1.4 \mathrm{E}-28$ & $1.9 \mathrm{E}-14$ \\
\hline
\end{tabular}

The packed stripping column is $6 \mathrm{~m}$ high and $0.6 \mathrm{~m}$ in diameter, packed with polypropylene polyhedral hollow ball (Chempack Co. 2007).

In the energy utilizing heat exchanger, feed wastewater is heated to $95{ }^{\circ} \mathrm{C}$ using the heat of the bottom product. The steam is produced by an electric heater at $120^{\circ} \mathrm{C}$ and 2 bar.

The bottom product, similar to that of the air stripper, practically does not contain AOX compounds. The concentration of the VOC in the distillate is usually high enough, and therefore it can be considered for possible reuse and/or utilization. It can be used again as solvent or it can be utilized as heat source in an incinerator (Fig. 6).

\section{Results and discussion}

Comparison of the two systems

To be able to compare the two plants, they are simulated with equal capacity and purification efficiency. Thus, the wastewater is introduced at the top of the column with
$20 \mathrm{~m}^{3} / \mathrm{h}$ flow rate in both systems. The removal of the organic halogen compounds is similar in both cases.

The efficiency of AOX removal

Table 2 shows the AOX components of the wastewater entering and leaving the air stripping and the steam stripping plants. The wastewater output compositions are simulated results. The small numbers can be interpreted that the removal of the AOX compounds is total in both cases.

In both cases, the concentration of the main AOX components in the wastewater leaving the stripping plants is therefore well below the limit [28/2004. (XII. 25.) Ministry of Environment Regulation 2004].

Efficiency of steam stripping to obtain concentrated pollutants in the distillate

The pollutant content in the input and output streams, distillate, of the steam stripping plant is also examined, with regard to the major organic halogen compounds. In the case of steam stripping, the volume of the head product, distillate, is significantly lower than the volume of the feed and, as a consequence, the concentrations of the pollutants are much higher (Table 3). Due to the small volume of the head product, the amount of material, and therefore the cost of the incineration can be decreased compared to the case when no stripper is applied and even reutilization of the organic compounds can be considered.

Treatment steps and operability features

With air stripping the wastewater treatment is accomplished in four steps:

1. stripping

2. catalytic oxidation

3. gas cleaning 
Table 3 Efficiency concentration of steam stripping

\begin{tabular}{llll}
\hline $\begin{array}{l}\text { Main AOX } \\
\text { compounds }\end{array}$ & $\begin{array}{l}\text { Wastewater } \\
\text { input (ppm) }\end{array}$ & $\begin{array}{l}\text { Distillate } \\
\text { output } \\
(\mathrm{ppm})\end{array}$ & $\begin{array}{l}\text { Efficiency of } \\
\text { concentration } \\
(\%)\end{array}$ \\
\hline Dichloromethane & 1,020 & 3,288 & 322 \\
Trichloroethylene & 7.15 & 23 & 322 \\
\hline
\end{tabular}

4. deposition of the salt

During the stripping and neutralization of the AOX compounds, the polluting changes phases twice (liquid $\rightarrow$ gas $\rightarrow$ liquid). Salt containing wastewater is produced during neutralization, which has to be deposited.

With steam stripping, the wastewater treatment is accomplished in two steps:

1. stripping

2. incineration

The stripped pollution is condensed at the end of the process and therefore only one phase change occurs (liquid $\rightarrow$ gas).

The comparison of the treatment steps of the two alternatives shows the easier operable alternative, that is the steam stripper.

Energetic factors

\section{Air stripping}

Energy integration is applied and the heat of the flue gas flow leaving the KATOX is used in a heat exchanger to preheat the gas stream entering the KATOX unit. Such an energy integration increases the temperature of the gas feed by $350{ }^{\circ} \mathrm{C}$. The power requirement of the electric heater is $118 \mathrm{~kW}$ if energy integration is applied. Without energy integration, it would be $422 \mathrm{~kW}$.

Due to the heat released during the catalytic oxidation, the electric heater of the KATOX has to be operated only at the start to reach $500{ }^{\circ} \mathrm{C}$ necessary for the process.

\section{Steam stripping}

In the case of steam stripping, similar kind of energy integration is applied like in the case of the air stripping. The feed stream is preheated with the bottom product of the stripper. Preheating the wastewater to $96{ }^{\circ} \mathrm{C}$ enables more efficient stripping of the pollutants, and the heating requirement can be reduced. According to our calculations, the power of the heating could be decreased from 306 to $296 \mathrm{~kW}$ since electric-heated boiler is applied.
Table 4 Comparison of cost elements of air and steam stripping alternatives

\begin{tabular}{lrcl}
\hline $1,000 € / \mathrm{a}$ & $\begin{array}{l}\text { Air } \\
\text { stripper }\end{array}$ & $\begin{array}{l}\text { Steam } \\
\text { stripper }\end{array}$ & $\begin{array}{l}\text { Comparison } \\
(\%)\end{array}$ \\
\hline $\begin{array}{l}\text { Investment costs } \\
\text { Heat exchanger(s) }\end{array}$ & 19 & 283 & \\
Electric heating & 81 & 175 & \\
Stripping column & 194 & 70 & \\
Scrubber & 70 & & \\
KATOX & 339 & & \\
Total-5 years amortization & 141 & 106 & \\
Operating costs & & & \\
Electrical energy & 110 & 53 & \\
Potable and deionized water & 40 & 6 & \\
Chemicals & 41 & & \\
Placement and treatment of & 99 & 192 & \\
$\quad$ end products & & & \\
Total & 290 & 252 & \\
Total cost & & 358 & \\
& 431 & 358 & \\
\hline
\end{tabular}

\section{Cost estimation}

During the calculations, the functions published by Douglas (1989) are used to estimate the capital cost of the equipment items. The capital costs are determined according to the major technological parameters of each units. The cost figures are updated using the Marshall \& Swift Index (Lozowski 2011). Five-year amortization of capital cost is assumed for total cost estimation.

The operational cost values are determined on the basis of the energy requirements considered for the whole stripping process; e.g., in the case of air stripping, besides the stripper the oxidation (KATOX), the scrubber, the water and chemicals, and deposition costs are all considered.

The total annual cost (TAC) can be estimated in many different ways. For the sake of simplicity, in our study, a simplified model shown in Eq. 3 is selected.

$$
\begin{aligned}
\text { Total annual cost }(\$ / \text { year })= & \frac{\text { Capital cost }}{\text { years of amortiztion }} \\
& + \text { operation cost. }
\end{aligned}
$$

Table 4 presents the cost elements considered during the calculation of investment and operating costs. The percentages show the cost elements of the steam and the air stripping plant. At the placement of end products, the Governmental Regulations of Ministry of Environment Regulation 2004; 220/2004. (VII. 21.) are followed. At the 
cost estimation of the treatment of end products, the prices of Budapest Sewage Works Ltd. (2013) are applied.

It can be seen that the investment cost of the air stripping plant is approximately $150 \%$ of the steam stripping plant.

Seven thousand two hundred annual working hours are selected for the calculation of the operating cost. This means continuous operation. The operating costs contain the annual costs of the utilized electricity, water and chemicals. In the case of the air stripping plant, the annual fine for releasing the saline liquid into the sewage system is also included, while for the steam stripping plant, the annual cost of incinerating the stripped and condensed compounds is taken into account. The total cost of the steam stripping plant is $83 \%$ of the air stripping plants.

Application of the results in the industry

The results of the comparison of the economic and operability features motivate the industry to select the greener technology to complete. In the praxis of the authors, five distillation columns have been built up till now to treat process wastewaters of pharmaceutical industry. The aim of the application of this physicochemical treatment technology is to remove the polluting, usually volatile, compounds from the wastewaters. According to the current praxis, the air stripper is replaced with a steam stripper that is easier to operate and also cheaper. Moreover, the top product can be reused and these features offer the greener technological alternative.

Figure 7 shows the newest completed design of the authors. This column, on the one hand, decreases the AOX of the process wastewater below $0.5 \mathrm{ppm}$ and, on the other hand, the distillate is clean organic solvent that can be reused in or out of the technology.

The completed steam-based stripping establishes a new green technology that is easy to operate economically. Applying this technology, the prescribed emission limits can be fulfilled easily.

\section{Conclusion}

Both air stripping and steam stripping are suitable methods for removing volatile and AOX compounds. There is a dispute among the engineers which one should be preferred. Our work is based on a real industrial case study, but modeling is also applied. The results show a clear decision: in spite of that the steam stripping uses steam that is more expensive than the air, finally it comes out cheaper because the additional costs of the air stripping are too high.

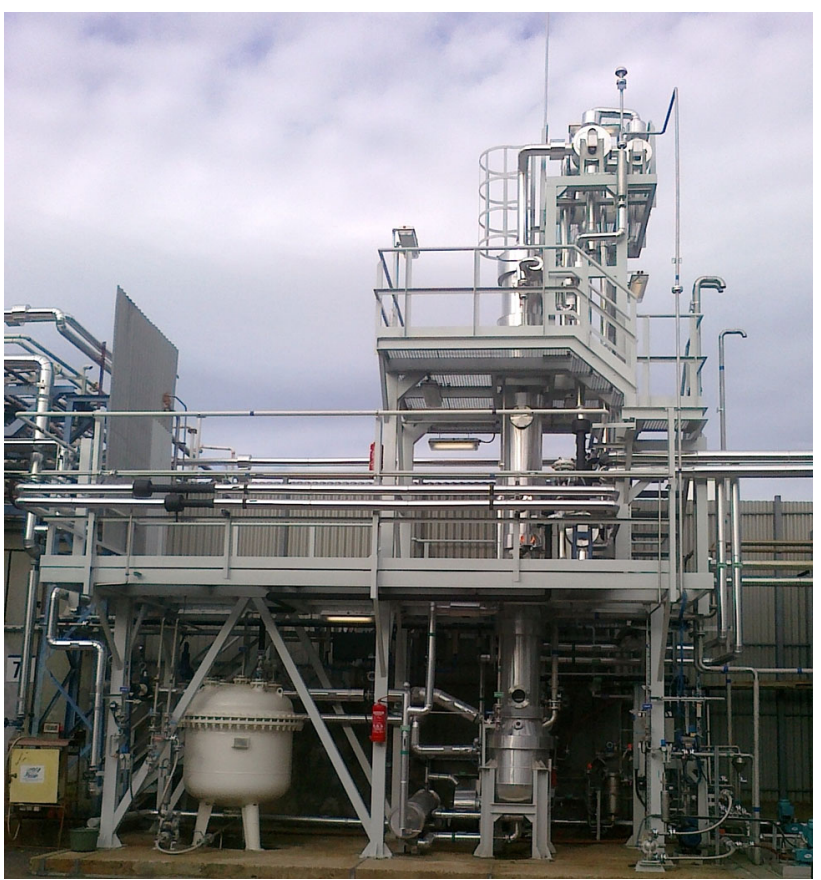

Fig. 7 Industrial column operated with steam to remove AOX from process wastewater

Moreover, the operation of the steam stripping is much simpler and it can offer the option of reutilizing the removed organic compounds obtained in the distillate. Such an option contributes also to the sustainable production with the reduction of the organic solvent consumptions.

Acknowledgments The authors would like to acknowledge the financial help of KMR-12-1-2012-0066, TAMOP-4-.2.2.A-11/1/ KONV-2012-0072 and SH 7/2/14 Swiss-Hungarian Joined project.

\section{Abbreviations \\ $€ /$ Euro/annual \\ AOX Adsorbable organically bound halogens \\ KATOX Catalytic oxidation \\ VOC Volatile organic compounds}

\section{References}

Alfke G, Bunch G, Crociani G, Dando D, Fontaine M, Goodsell P, Green A, Hafker W, Isaak G, Marvillet J, Poot B, Sutherland H, van der Rest A, van Oudenhoven J, Walden T (1999) Best available techniques to reduce emission from refineries. CONCAWE. Document no. 99/01. Accessed 11 Mar 2013. http://193. 219.133.6/aaa/Tipk/tipk/4_kiti\%20GPGB/43.pdf 
Asia IO, Akporhonor EE (2007) Characterization and physicochemical treatment of wastewater from rubber processing factory. Int J Phys Sci 2:61-67

Bajnoczy G (2013) http://enfo.agt.bme.hu/drupal/sites/default/files/ ea-CHCl\%20dioxin.pdf (in Hungarian). Accessed 23 Aug 2013

Basakcilardan-kabakci S, Ipekoglu AN, Talinli I (2007) Recovery of ammonia from human urine by stripping and absorption. Environ Eng Sci 24:615-624. doi:10.1089/ees2006.0412

Bundesministerium für Umwelt, Naturschutz und Reaktorsicherheit (BMU) (2000) Hinweise und Erläuterungen zu Anhang 22 der Abwasserverordnung. Book, Germany

Budapest Sewage Works Ltd. (2013) Sewer usage charge. http://fcsm. hu/hu/ugyfelszolgalat/szolgaltatasi_dijak/csatornahasznalati_dij/ . Accessed 7 Mar 2013

Chempack Co. (2007) Polyhedral hollow ball. http://www.chemicalpacking.com/products/plastic/2007-08-25/33.html. Accessed 11 Mar 2013

DIN 38409-H14 (1996) Water quality determination of adsorbable organically bound halogens (AOX)

Douglas JM (1989) Conceptual design of chemical processes. McGrew-Hill, New York, pp 568-580

Driscoll TP, Barber JB, Chandran K, Constable S, Darnell C, DiMenna R, Gaines B, Goodman A, Hlavek R, Johns FJ, Jones TS, Kemp G, Kim B, Krill WP, Maillacheruvu K, Millano EF, Nichols C, Parham G, Philbrook D, Severin BF, Shamas J, Shamskhorzani R, Solvie J, Venkatasubbiah V, Wirtz R, WongChong G, Yeh B, Young J (2008) Industrial wastewater management, treatment, and disposal. WEF manual of practice no. FD-3rd. Mcgraw-Hill, New York, pp 474-489

Ecker A, Winter B (2000) Stand der Technik bei Raffinerien im Hinblick auf die IPPC-Richtlinie. Monographien, Band 119. Umweltbundesamt GmbH, Federal Envionment Agency, Wien, Austria. http://www.umweltbundesamt.at/fileadmin/site/ publikationen/M119z.pdf. Accessed 11 Mar 2013

ENTEC UK Ltd. (1996) Cost-effective separation technologies for minimising wastes and effluents. Report. Environmental technology best practice programme, guide GG37

European Environment Agency (EEA) (1997) Effluent treatment techniques-technical guidance note (abatement) no. A4, UK

Ferrer J, Seco A, Serralta J, Ribes J, Manga J, Asensi E, Morenilla JJ, Llavador F (2008) DESASS: a software tool for designing, simulating and optimising WWTPs. Environ Model Softw 23:19-26. doi:10.1016/j.envsoft.2007.04.005

Fredenslund A, Jones RL, Prausnitz JM (1975) Group-contribution estimation of activity coefficients in nonideal liquid mixtures. AlChE J 21:1086-1099. doi:10.1002/aic.690210607

Gmehling J, Menke J, Krafczyk J, Fischer K (1994) Azeotropic data, part I. Wiley-VCH, Weinheim

Gonzalez-Velasco JR, Aranzabal A, Gutierrez-Ortiz JI, LopezFonseca R, Gutierrez-Ortiz MA (1998) Activity and product distribution of alumina supported platinum and palladium catalysts in the gas-phase oxidative decomposition of chlorinated hydrocarbons. Appl Catal B Environ 19:189-197. doi:10.1016/ S0926-3373(98)00078-2

Government Regulation (2004) 220/2004. (VII. 21.). Accessed 7 Mar 2013. http://www.complex.hu/jr/gen/hjegy_doc.cgi?docid=A04002 20.KOR

IPPC reference document on best available techniques in common waste water and waste gas treatment/management systems in the chemical sector (2002) Applied treatment technology. European Commission, Brussels (EU), pp 124-127

Koczka K (2009) Environmental conscious design and industrial application of separation processes. Dissertation, BME, Budapest, Hungary

Koczka K, Mizsey P (2010) New area for distillation: wastewater treatment. Per Pol Chem Eng 54:41-45. doi:10.3311/pp.ch.2010-1.06
Köhler A, Hellweg S, Recan E, Hungerbühler K (2007) Inputdependent life-cycle inventory model of industrial wastewatertreatment processes in the chemical sector. Environ Sci Technol 41:5515-5522

Lapkin A, Constable D (2008) Green chemistry metrics. Measuring and monitoring sustainable processes. Wiley-VHC, Weinheim

Lozowski D (2011) Ecomomic indicators. Chem Eng 118:55-56

Major ZS (2008) AOX removal from pharmaceutical process wastewater by air and steam stripping. M.Sc. thesis, BME, Budapest, Hungary

Marsili-Libelli S (2010) Modelling and automation of water and wastewater treatment processes. Environ Model Softw 25:613-615. doi:10.1016/j.envsoft.2009.11.002

Ministry of Environment Regulation (2004). 28/2004. (XII. 25.). Accessed 7 Mar 2013. http://www.complex.hu/jr/gen/hjegy_doc. cgi? docid=A0400028.KVV

Mizsey P (1991) A global approach to the synthesis of entire chemical processes. Dissertation, ETH, Zürich, Switzerland

Mizsey P (1994) Waste reduction in the chemical industry-a two level problem. J Hazard Mater 37:1-13. doi:10.1016/03043894(94)85028-3

Mizsey P, Toth AJ (2012) Application of the principles of industrial ecology for the treatment of process waste waters with physicochemical tools. Ind Ecol 1:101-126 (in Hungarian)

Mizsey P, Koczka K, Tungler A (2008) Treatment of process wastewaters with physicochemical tools. Hung $\mathbf{J}$ Chem 114:107-113 (in Hungarian)

Mohammad-Hosseini A, Bakos V, Jobbágy A, Tardy G, Mizsey P, Makó M, Tungler A (2011) Co-treatment and utilisation of liquid pharmaceutical wastes. Per Pol Chem Eng 55:3-10. doi:10.3311/ pp.ch.2011-1.01

North Ostrobothnia Regional Environment Centre (NOREC) (2000) Examples of waste water and waste gas treatment in the chemical industry in Finland. Report

Oguz H, Koch S, Weisweiler W (2000) Comparison of mechanistic models for the catalytic oxidation of trichloroethylene over $\mathrm{Cr} /$ $\mathrm{Al}_{2} \mathrm{O}_{3}$ and $\mathrm{Al}-\mathrm{Cr} /$ Porous glass catalysts. Chem Eng Technol 23:395-400. doi:10.1002/(SICI)1521-4125(200005)23:5<395: AID-CEAT395>3.0.CO;2-L

Quan XJ, Wang FP, Zhao QH, Zhao TT, Xiang JX (2009) Air stripping of ammonia in a water-sparged aerocycleone reactor. J Hazard Mater 170:983-988. doi:10.1016/j.hazmat.2009.05. 083

Quan X, Ye C, Xiong Y, Xiang J, Wang F (2010) Simultaneous removal of ammonia, $\mathrm{P}$ and $\mathrm{COD}$ from anaerobically digested piggery wastewater using an integrated process of chemical precipitation and air stripping. J Hazard Mater 178:326-332. doi:10.1016/j.hazmat.2010.01.083

Rivas A, Irizar I, Ayesa E (2008) Model-based optimisation of wastewater treatment plants design. Environ Model Softw 23:435-450. doi:10.1016/j.envsoft.2007.06.009

Sackewitz M (1999) Luftstrippverfahren zur Teilstrombehandlung. Betriebserfahrungen auf den Kläranlagen Göttingen und Cuxhaven. Umwelt 29:16-18

Saracco G, Genon G (1994) High temperature ammonia stripping and recovery from process liquid wastes. J Hazard Mater 37:191-206. doi:10.1016/0304-3894(94)85048-8

Sattler K (1977) Thermische Trennverfahren. Würzburg, Vogel, p 3.7

Seiss M, Gahr A, Niesser R (2001) Improved AOX degradation in UV oxidative wastewater treatment by dialysis with nanofiltration membrane. Water Res 35:3242-3248. doi:10.1016/S00431354(01)00028-8

Simoni LD, Lin Y, Brennecke JF, Stadtherr MA (2008) Modeling liquid-liquid equilibrium of ionic liquid systems with NRTL, electrolyte-NRTL, and UNIQUAC. Ind Eng Chem Res 47:256-272. doi:10.1021/je70956j 
Toth AJ, Gergely F, Mizsey P (2011) Physicochemical treatment of pharmaceutical wastewater: distillation and membrane processes. Per Pol Chem Eng 55:59-67. doi:10.3311/pp.ch.2011-2. 03

Wang Y, Pelkonen M, Kotro M (2010) Treatment of high ammoniumnitrogen wastewater from composting facilities by air stripping and catalytic oxidation. Water Air Soil Pollut 208:259-273. doi:10.1007/s11270-009-0164-Z 